\begin{tabular}{l} 
DURNAI, RIS'T \\
(Rekajasa Sistem dan Teknologi Informasi) \\
Vol.3 No.3 (2019) $511-517 \quad$ ISSN Media Elektronik: 2580-0760 \\
\hline
\end{tabular}

\title{
Perancangan Sistem Pendukung Keputusan Untuk Pemilihan Lokasi Dalam Perluasan Usaha Kafe menggunakan Analytical Hierarchy Process
}

\author{
Wowon Priatna ${ }^{1}$, Suryadi $^{2}$ \\ ${ }^{1}$ Teknik Informatika, Teknik, Universitas Bhayangkara Jakarta Raya \\ ${ }^{2}$ Teknik Informatika, Universitas Pelita Bangsa \\ ${ }^{1}$ wowon.priatna@dsn.ubharajaya.ac.id, ${ }^{2}$ suryadii400@gmail.com
}

\begin{abstract}
The Milk Café is a business in the field of milk concoctions with appetizing flavors like chocolate, strawberry, greentea, vanilla. The Milk Café was founded in 2015 which currently has 3 branches and 5 franchises in various cities in Central Java and D.I. Yogyakarta and many more. the milk café owner has plans to open a new café branch. The milk café owner does not yet have the right method for determining location selection recommendations. Currently, café owners only conduct surveys and then choose locations that they think are appropriate based on several criteria so that café owners are often hesitant in determining the right location. Choosing an improper business location can cause bankruptcy or failure to run a business. This study aims to find out how the AHP method is able to provide problem solving solutions in the selection of locations in the expansion of the café business. And how to build a decision support system application AHP method. The data used are location data to conduct a feasibility survey based on criteria data to locations that have been determined by the team leader, where the criteria for determining new cafes are strategic locations, market share, competitors, rental prices and area size ... results from AHP calculations for expansion of the café is that it can be concluded that the alternative location of Jl. Sultan Syahrir Surakarta was stated as the most suitable location to be chosen as the location of the new branch of The Milk Café with the highest weighting value of 0.235 . While the least recommended alternative locations are Jl. Adi Soemarmo with the least total weight is 0.153 .
\end{abstract}

Keywords: Decision Support System (DSS), Business Location, Business Expansion, Cafe, Analytical Hierarchy Process, AHP, Unified language Modeling, UML.

\begin{abstract}
Abstrak
The Milk Café adalah sebuah usaha dibidang racikan susu dengan rasa yang menggugah selera seperi, coklat, strawberry, greentea, vanilla. The Milk Café berdiri sejak tahun 2015 dimana saat ini telah memiliki 3 cabang dan 5 franchise di berbagai kota di Jawa Tengah dan D.I. Yogyakarta dan masih banyak lagi. pemilik the milk café mempunyai rencana untuk membuka cabang café baru. Pemilik the milk café belum mempunyai metode yang tepat untuk menentukan rekomendasi pemilihan lokasi. Saat ini pemilik kafé dalam melakukan pemilihan lokasi hanya melakukan survey dan kemudian memilih lokasi yang menurutnya tepat berdasarkan beberapa kriteria sehingga pemilik café seringkali ragu-ragu dalam menentukan lokasi yang tepat, Pemilihan lokasi bisnis yang tidak tepat dapat menyebabkan kebangkrutan atau kegagalan dalam menjalankan bisnisnya. Penelitian ini bertujuan untuk mengetahui bagaimana metode AHP mampu memberikan solusi pemecahan masalah dalam pemilihan lokasi dalam perluasan usaha bisnis café. Serta bagaimana membangun sebuah aplikasi sistem pendukung keputusan metode AHP. Data yang digunakan adalah data lokasi untuk melakukan survei kelayakan berdasarkan data kriteria ke lokasi-lokasi yang telah ditentukan kepala team, dimana kriteria untuk penentunan café baru adalah lokasi strategis, pangsa pasar, kompetitor, harga sewa dan luas area.. hasil dari perhitungan AHP untuk perluasan café adalah ini dapat disimpulkan bahwa alternatif lokasi Jl. Sultan Syahrir Surakarta dinyatakan sebagai lokasi yang paling cocok untuk dipilih sebagai lokasi cabang baru The Milk Café dengan bobot nilai paling tinggi yaitu 0,235. Sementara alternatif lokasi yang paling tidak direkomendasikan adalah alternatif lokasi Jl. Adi Soemarmo dengan total bobot paling sedikit yaitu 0,153.
\end{abstract}

Kata kunci: Sistem Pendukung Keputusan (SPK), Lokasi Bisnis, Perluasan Usaha, Kafe, Analytical Hierarchy Process, AHP, Unified language Modeling, UML 


\section{Pendahuluan}

The Milk Café adalah sebuah usaha dibidang racikan 2.1 Tahapan Penelitian susu dengan rasa yang menggugah selera seperi, coklat, strawberry, greentea, vanilla. The Milk Café berdiri Sistem yang dirancang ini sebagai sebuah model sejak tahun 2015 dimana saat ini telah memiliki 3 penentuan lokasi Cafe menggunakan metode AHP. cabang dan 5 franchise di berbagai kota di Jawa Metode AHP pada penelitian ini digunakan untuk Tengah dan D.I. Yogyakarta dan masih banyak lagi. menyusun struktur masalah dengan mengembangkan pemilik the milk café mempunyai rencana untuk model keterkaitan, yaitu untuk menentukan sasaran membuka cabang café baru. Pemilik the milk café atau tujuan yang diinginkan yaitu untuk penentuan belum mempunyai metode yang tepat untuk lokasi cafe, menentukan kriteria pada yang tepat dan menentukan rekomendasi pemilihan lokasi. Saat ini selanjutnya dibentuk matriks perbandingan pemilik kafé dalam melakukan pemilihan lokasi hanya berpasangan untuk melakukan pembobotan dari melakukan survey dan kemudian memilih lokasi yang beberapa kriteria, pembobotan ini dilakukan untuk menurutnya tepat berdasarkan beberapa kriteria memperlihatkan ketergantungan antara ukuran sehingga pemilik café seringkali ragu-ragu dalam parameter penilaian yang satu dengan yang lain. menentukan lokasi yang tepat, Pemilihan lokasi bisnis Sehingga diperoleh bobot kriteria yang digunakan yang tidak tepat dapat menyebabkan kebangkrutan atau dalam proses perhitungan untuk memperoleh alternatif kegagalan dalam menjalankan bisnisnya. salah Salah penilaian penentuan lokasi cafe. Setelah didapatkan satu metode dalam sistem pengambilan keputusan hasil dari perhitungan AHP digunakan sebagai kriteria adalah Analytical Hierarki Process (AHP). AHP [1] untuk membangun aplikasi berbasis web dengan php merupakan suatu model Model pendukung keputusan dan media penyimpanan digunakan mysql.

yang akan menguraikan masalah multi faktor atau multi kriteria yang kompleks menjadi suatu hirarki untuk membantu pengambilan keputusan dalam situasi yang semi terstruktur dan situasi yang tidak terstruktur, dimana tidak seorangpun tahu secara pasti bagaimana keputusan dibuat[2].

Penelitian Frieyadie dan Ramadhan (2018)[3] menerapkan AHP ntuk membantu siswa memilih Jurusan Yang tepat di SMK sehingga membantu sekolah khususnya untuk menentukan beberapa persoalan mengenai pemilihan jurusan. Sedangkan [4] menerapkan AHP dalam menentukan Mitra Usaha berprestasi.

Pada penelitian Kyaw dan Lai Lai (2014)[5] menggunakan AHP dalam pencarin tenaga kerja dengan menentukan salary, location, job content, and long term prospect. Sistem yang diusulkan mendukung keputusan tidak hanya dipekerjaan yang diinginkan untuk pencari kerja tetapi juga memberikan posisi pekerjaan sesuai dengan lowongan pekerjaan yang tersedia. System diimplementasi menggunakan ASP.net dan media penyimpan dengan sql server.

Pada penelitian Sri dan Sari (2000)[6] mengembangkan Sistem Pendukung Keputusan (SPK) dengan memanfaatkan metode Analytical Hierarchy Process $(A H P)$ sebagai proses dalam pemilihan Cafe terbaik. Sedangkan Untuk menentukan Cafe terbaik, cafe harus memenuhi kriteria-kriteria yang telah ditentukan, yaitu 2.3 Metode Analisis Data

rasa, harga, suasana, pelayanan, fasilitas dan kebersihan.

Dari latar belakang dan penelitian diatas Analytical analisa data berfungsi untuk menyimpulkan hasil dari Hierarchy Process $(A H P)$ dapat diterapkan sebagai penelitian. Pada tahap ini dilakukan penganalisaan metode sistem pendukung keputusan untuk menentukan kriteria dan data lokasi. Data kriteria adalah data-data pemilihan lokasi milk café berdasarkan kriteria yang mengenai kriteria yang dipertimbangkan antara satu ditentukan.

\subsection{Metode Pengumpulan Data}

Tahapan penelitian kajian tentang penerapan metode AHP (Analytical Hierarchy Process) dalam pemilihan lokasi dalam perlusaan Cafe di café milk dijelaskan secara umum sebagai berikut:

Tahapan awal adalah mengumpulkan bahan literatur sebagai referensi dan informasi terkait.

b. Wawancara

metode yang digunakan untuk memperoleh data dengan cara mengajukan pertanyaan-pertanyaan secara langsung. Dalam hal ini penulis melakukan wawancara dengan pemilik Kafe "The Milk Café" tentang bagaimana beliau mengambil keputusan pemilihan lokasi cabang baru.

c. Menentukan identifikasi masalah melakukan identifikasi tentang masalah yang akan dibahas, berkaitan dengan penerapan metode AHP (Analytical Hierarchy Process) dalam pemilihan perlukasan lokasi di milk café.

d. Studi Pustaka

mempelajari literatur berupa buku-buku teori tentang Sistem Pendukung Keputusan, Metode penelitian, AHP, dan jurnal-jurnal yang akan digunakan sebagai kajian teori dalam penelitian

Teknik analisa data merupakan salah satu langkah yang
paling menentukan dari sebuah penelitian, karena
analisa data berfungsi untuk menyimpulkan hasil dari
penelitian. Pada tahap ini dilakukan penganalisaan
kriteria dan data lokasi. Data kriteria adalah data-data
mengenai kriteria yang dipertimbangkan antara satu
alternatif lokasi café dengan yang lain. data lokasi yang
Tahap ini melanjutkan penelitian dengan cara 
akan dijadikan sebagai cabang baru café yang potensial. Data-data lokasi tersebut merupakan calon lokasi yang akan dipilih untuk pembangunan café. Data yang dimasukan kedalam sistem ini adalah data simulasi atau bukan data yang sebenarnya, data ini digunakan hanya untuk kepentingan implementasi data pengujian sistem ini.

\subsection{Analisa Metode AHP}

Peralatan utama AHP adalah sebuah hierarki fungsional dengan input utamanya persepsi manusia. Dengan hierarki suatu masalah kompleks dan tidak terstruktur dipecahkan kedalam kelompok-kelompoknya. Adapun tahapan metode AHP [7][8][9] untuk menentukan lokasi café adalah:

1. Mendefinisikan masalah dan menentukan solusi yang diinginkan

2. Membuat struktur hierarki yang diawali dengan tujuan umum, dilanjutkan dengan kriteria-kriteria dan alternatif- alternatif pilihan. Struktur hirarki AHP dapat dilihat pada gambar 1.

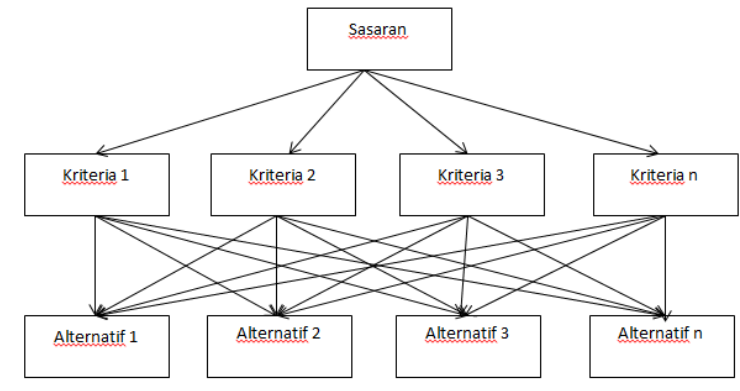

Gambar 1. Struktur hirarki AHP

3. Menentukan prioritas elemen

4. Sintesis adalah Pertimbangan-pertimbangan terhadap perbandingan berpasangan disintesis untuk memperoleh keseluruhan prioritas. Hal-hal yang dilakukan dalam langkah ini adalah:

1) Menjumlahkan nilai-nilai pada setiap kolom pada matriks.

2) Membagi setiap nilai dari kolom dengan total kolom yang bersangkutan untuk memperoleh normalisasi matriks.

3) Menjumlahkan nilai-nilai dari setiap baris dan membaginya dengan jumlah elemen untuk mendapatkan nilai rata-rata

5. Mengukur Konsistensi adalah untuk mengetahui seberapa baik konsistensi yang ada karena kita tidak menginginkan keputusan berdasarkan pertimbangan dengan konsistensi yang rendah. Hal-hal yang dilakukan dalam langkah ini adalah:

1) Kalikan setiap nilai pada kolom pertama dengan prioritas relative elemen pertama, nilai pada kolom kedua dengan prioritas relative elemen kedua, dan seterusnya.

2) Jumlahkan setiap baris.
3) Hasil dari penjumlahan baris dibagi dengan elemen prioritas relative yang bersangkutan

4) Jumlahkan hasil bagi diatas dengan banyaknya elemen yang ada, hasilnya disebut $\lambda$ maks.

6. Hitung Consistency Index (CI)

Sebelum menghitung CI, harus terlebih dahulu mencari nilai eigen vector $(\lambda)$ dengan menggunakan Persamaan (1-1)

$\lambda=\left(\sum a_{11-n 1} \times \overline{x_{1}}\right)+\cdots+\left(\sum a_{1 n-n 1} \times \overline{x n}\right)$

$\mathrm{CI}=(\lambda$ maks $-\mathrm{n}) / \mathrm{n}-1$

Dimana $\mathrm{n}=$ banyaknya elemen

7. Hitung rasio konsistensi/Consistency Ratio (CR) dengan rumus:

\section{$\mathrm{CR}=\mathrm{CI} / \mathrm{IR}$}

Dimana $\mathrm{CR}=$ Consistency Ratio $\mathrm{CI}=$ Consistency index $\mathrm{IR}=$ Indeks Random Consistency

8. Memeriksa konsistensi hierarki.

Jika nilainya lebih dari $10 \%$, maka penilaian data judgement harus diperbaiki. Namun jika rasio konsistensi (CI/IR) kurang atau sama dengan 0,1 maka hasil perhitungan bisa dinyatakan benar.

\section{5. Merancang Sistem Pendukung Keputusan}

Tahap ini adalah perancangan Aplikasi system pendukung keputusan. untuk perancangan system menggunakan Use case Diagram, Class diagram yang merupakan bagian dari unified Modeling language (UML) dan merancang interface dari aplikasi [9].

\section{Hasil dan Pembahasan}

Dalam menentukan kriteria pemilihan lokasi yang potensial untuk pembangunan sebuah café diperlukan beberapa kriteria yang digunakan. Lihat pada tabel 1 .

Dalam hal ini level alternatif diisi dengan nama calon lokasi café yang digambarkan dengan istilah alternatif, misalkan Alternatif 1, Alternatif 2 dan seterusnya.

Tabel 1. Kriteria yang digunakan

\begin{tabular}{cl}
\hline kriteria & Keterangan \\
\hline LS & Lokasi Strategis \\
PP & Pangsa Pasar \\
K & Kompetitor \\
HS & Harga Sewa \\
LA & Luas Area \\
\hline
\end{tabular}

Adapun struktur hirarki untuk menentukan lokasi potensial lokasi pendirian café dapat dilihat pada gambar 2 . 


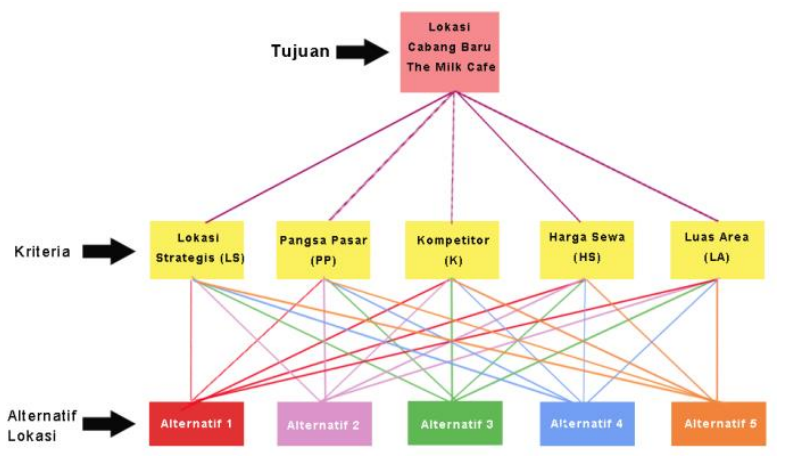

Gambar 2. Struktur hirarki untuk penentuan lokasi

Setelah menetapkan kriteria selanjutnya membuat matriks perbandingan berpasangan antar kriteria. perbandingan berpasangan antar kriteria ini bertujuan untuk mengetahui nilai bobot / prioritas elemen pada setiap kriteria. Matrik perbandingan kriteria dapat dilihat pada tabel 2. Pada tabel 2 perbandingan berpasangan kriteria adalah perbandingan baris terhadap kolom berdasarkan tingkat kepentingannya.

Tabel 2. Matriks Perbandingan Berpasangan Kriteria Prioritas

\begin{tabular}{cccccc}
\hline Kritera & LS & PP & K & HS & LA \\
\hline LS & LS/LS & LS/P & LS/K & LS/HS & LS/LA \\
PP & PP/LS & PP/PP & PP/K & PP/HS & PP/LA \\
K & K/LS & K/PP & K/K & K/HS & K/LA \\
HS & HS/LS & HS/PP & HS/K & HS/HS & HS/LA \\
LA & LA/LS & LA/PP & LA/K & LA/HS & LA/LA \\
Jumlah & $\mathrm{n}$ & $\mathrm{n}$ & $\mathrm{N}$ & $\mathrm{n}$ & $\mathrm{n}$ \\
\hline
\end{tabular}

Selanjutnya menentukan matrik perbandingan untuk aternatif kriteria. Pada tabel 3 adalah perbandingan berpasangan alternatif adalah perbandingan baris terhadap kolom berdasarkan tingkat kepentingan.

Tabel 3. Matriks Perbandingan berpasangan Alternatif Lokasi

\begin{tabular}{ccccc}
\hline Alternatif & AL1 & AL2 & AL 3 & ALn \\
\hline AL 1 & AL1/AL1 & AL1/AL2 & AL1/AL3 & AL1/Aln \\
Al 2 & AL2/AL1 & AL2/AL2 & AL2/AL3 & A12/ALn \\
AL3 & AL3/AL1 & AL3/AL2 & AL3/AL3 & AL3/ALn \\
AL n & ALn/AL1 & ALn/AL2 & ALn/AL3 & ALn/ALn \\
Jumlah & $\mathrm{N}$ & $\mathrm{n}$ & $\mathrm{n}$ & $\mathrm{n}$ \\
\hline
\end{tabular}

\subsection{Perhitungan Metode AHP Pemilihan Lokasi Kafé}

Berikut contoh perhitungan Sistem Pendukung Keputusan Metode Analytical Hierarcy Process. Data penilaian survei kelayakan lokasi yang dimasukan pada perhitungan ini bukanlah data sesungguhnya. Data ini hanyalah contoh dalam melakukan perhitungan SPK metode AHP.

1. Membuat matriks perbandingan berpasangan pada tahap ini dilakukan penilaian perbandingan berpasangan antar satu kriteria dengan kriteria yang lain. Hasilnya dapat dilihat pada tabel 4.
Tabel 4. Matriks Perbandingan Berpasangan Kriteria

\begin{tabular}{cccccc}
\hline Kritera & LS & PP & K & HS & LA \\
\hline LS & 1 & 1 & 2 & 3 & 3 \\
PP & 1 & 1 & 3 & 3 & 3 \\
K & $1 / 2$ & $1 / 3$ & 1 & 2 & 2 \\
HS & $1 / 3$ & $1 / 3$ & $1 / 2$ & 1 & 1 \\
LA & $1 / 3$ & $1 / 3$ & $1 / 2$ & 1 & 1 \\
\hline
\end{tabular}

Tata cara penilaian ini berdasarkan tingkat kepentingannya dalam perbandingan antar kriteria mengacu pada tabel 5 Skala Penilaian Perbandingan Berpasangan.

Tabel 5. Skala Penilaian Perbandingan Pasangan

\begin{tabular}{|c|c|}
\hline Intensitas Kepentingan & Keterangan \\
\hline 1 & Kedua elemen sama pentingnya \\
\hline 3 & $\begin{array}{l}\text { Elemen yang satu sedikit lebih penting } \\
\text { daripada elemen yang lainnya }\end{array}$ \\
\hline 5 & $\begin{array}{l}\text { Satu elemen jelas lebih mutlak penting } \\
\text { daripada elemen lainnya }\end{array}$ \\
\hline 7 & $\begin{array}{l}\text { Satu elemen jelas lebih mutlak penting } \\
\text { daripada elemen lainnya }\end{array}$ \\
\hline 9 & $\begin{array}{l}\text { Satu elemen mutlak penting daripada } \\
\text { elemen lainnya }\end{array}$ \\
\hline $2,4,6,8$ & $\begin{array}{l}\text { Nilai-nilai antara dua nilai } \\
\text { pertimbangan yangberdekatan }\end{array}$ \\
\hline Kebalikan & $\begin{array}{l}\text { Jika aktivitas i mendapat satu angka } \\
\text { dibandingkan dengan aktivitas } \mathrm{j} \text {, maka } \\
\mathrm{j} \text { memiliki nilai kebalikannya } \\
\text { dibandingkandengan i }\end{array}$ \\
\hline
\end{tabular}

Maka nilai perbandingan kriteria setelah dilakukan perhitungan didapatkan hasilnya dapat dilihat pada tabel 6 .

Tabel 6. Hasil Matriks Perbandingan Berpasangan Kriteria

\begin{tabular}{cccccc}
\hline Kritera & LS & PP & K & HS & LA \\
\hline LS & 1 & 1 & 2 & 3 & 3 \\
PP & 1 & 1 & 3 & 3 & 3 \\
K & 0.5 & 0.33 & 1 & 2 & 2 \\
HS & 0.33 & 0.33 & 0.5 & 1 & 1 \\
LA & 0.33 & 0.33 & 0.5 & 1 & 1 \\
Jumlah & 3.16 & 2.99 & 7 & 10 & 10 \\
\hline
\end{tabular}

2. Membuat matriks Bobot Pioritas kriteria

Matriks nilai bobot kriteria diperoleh dari tahapan metode ahp pada bagian sintesis. Hasil perhitungan dapat dilihat pada tabel 7 .

Tabel 7. Perhitungan Bobot Prioritas Kriteria

\begin{tabular}{cccccccc}
\hline & $\mathrm{LS}$ & $\mathrm{PP}$ & $\mathrm{K}$ & $\mathrm{HS}$ & $\mathrm{LA}$ & $\mathrm{jmh}$ & $\mathrm{BP}$ \\
\hline $\mathrm{LS}$ & $1 / 3.16$ & $1 / 2.99$ & $2 / 7$ & $3 / 1$ & $3 / 1$ & 1.5 & 0.3 \\
& & & & 0 & 0 & 4 & 1 \\
$\mathrm{PP}$ & $1 / 3.16$ & $1 / 2.99$ & $3 / 7$ & $3 / 1$ & $3 / 1$ & 1.6 & 0.3 \\
& & $0.33 / 2.9$ & & 0 & 0 & 8 & 4 \\
$\mathrm{~K}$ & $0.5 / 3.16$ & 9 & $1 / 7$ & $2 / 1$ & $2 / 1$ & 0.8 & 0.1 \\
$\mathrm{H}$ & $0.33 / 3.1$ & $0.33 / 2.9$ & $0.5 /$ & $1 / 1$ & 0 & 1 & 6 \\
$\mathrm{~S}$ & 6 & 9 & 7 & 0 & 0 & 9 & 0 \\
$\mathrm{~L}$ & $0.33 / 3.1$ & $0.33 / .29$ & $0.5 /$ & $1 / 1$ & $1 / 1$ & 0.4 & 0.1 \\
$\mathrm{~A}$ & 6 & 9 & 7 & 0 & 0 & 9 & 0 \\
\hline
\end{tabular}




\section{Mengecek Nilai CR}

Tujuannya adalah untuk mengetahui konsistensi matriks perbadingan. Maka dilakukan perkalian seluruh isi kolom matriks perbandingan tabel 7. kriteria LS dengan bobot prioritas tabel 8. kriteria LS, isi kolom PP dengan bobot prioritas kriteria PP dan seterusnya. Kemudian dijumlahkan setiap besarnya dan dibagi penjumlahan baris dengan bobot prioritas bersesuaian seperti terlihat pada tabel 8 .

Tabel 8. Matriks Perhitungan Bobot Konsistensi

\begin{tabular}{|c|c|c|c|c|c|c|c|}
\hline & $\mathrm{LS}$ & PP & $\mathrm{K}$ & $\mathrm{HS}$ & LA & jmh & BP \\
\hline LS & $\begin{array}{c}1 \mathrm{x} \\
0.31\end{array}$ & $\begin{array}{c}1 \mathrm{x} \\
0.34\end{array}$ & $\begin{array}{c}2 \mathrm{x} \\
0.16\end{array}$ & $\begin{array}{c}3 \mathrm{x} \\
0.10\end{array}$ & $\begin{array}{c}3 x \\
0.10\end{array}$ & 1.55 & 5.05 \\
\hline PP & $\begin{array}{c}1 \mathrm{x} \\
0.31\end{array}$ & $\begin{array}{c}1 \mathrm{x} \\
0.34\end{array}$ & $\begin{array}{c}3 \mathrm{x} \\
0.16\end{array}$ & $\begin{array}{c}3 \mathrm{x} \\
0.10\end{array}$ & $\begin{array}{c}3 \mathrm{x} \\
0.10\end{array}$ & 1.71 & 5.1 \\
\hline $\mathrm{K}$ & $\begin{array}{l}0.5 \mathrm{x} \\
0.31\end{array}$ & $\begin{array}{c}0.33 x \\
0.34\end{array}$ & $\begin{array}{c}1 \mathrm{x} \\
0.16\end{array}$ & $\begin{array}{c}2 \mathrm{x} \\
0.10\end{array}$ & $\begin{array}{c}2 \mathrm{x} \\
0.10\end{array}$ & 0.81 & 5.03 \\
\hline HS & $\begin{array}{c}0.33 x \\
0.31\end{array}$ & $\begin{array}{c}0.33 \mathrm{x} \\
0.34\end{array}$ & $\begin{array}{l}0.5 \mathrm{x} \\
0.16\end{array}$ & $\begin{array}{c}1 \mathrm{x} \\
0.10\end{array}$ & $\begin{array}{c}1 \mathrm{x} \\
0.10\end{array}$ & 0.49 & 5.02 \\
\hline LA & $\begin{array}{c}0.33 x \\
0.31\end{array}$ & $\begin{array}{c}0.33 x \\
0.34\end{array}$ & $\begin{array}{l}0.5 x \\
0.16\end{array}$ & $\begin{array}{c}1 \mathrm{x} \\
0.10\end{array}$ & $\begin{array}{c}1 \mathrm{x} \\
0.10\end{array}$ & 0.49 & 5.02 \\
\hline
\end{tabular}

Mengacu pada rumus persamaan (1-1) sehingga didapatkan eigen vector $(\lambda)=5.052$. Setelah didapatkan nilai eigen vector, tahap selanjutnya menghitung $C I$. Nilai CI mengacu pada rumus persamaan (1-2) maka didapatkan $\mathrm{CI}=0.013$.

Tahap selanjutnya adalah menghitung rasio konsistensi/Consistency Ratio (CR). mengacu pada rumus (1-3) makadidaptkan nilai $\mathrm{CR}=0.012$. Karena $\mathrm{CR}<10 \%$ maka perbandingan dinyatakan konsisten $100 \%$.

\section{Melakukan Perbandingan Antar alternatif}

Tujuanya adalah untuk mendapatkan nilai bobot alternatif disetiap kriteria. Setelah menemukan bobot prioritas kriteria, dengan cara yang sama seperti perhitungan pada tabel 6 dan tabel 7. dapat ditemukan alternatif lokasi yang akan direkomendasikan untuk pembangunan kafe berdasarkan perhitungan masingmasing kriteria dalam penilaian. Berikut data nilai hasil survei kelayakan yang telah dilakukan di lima lokasi di kota Surakarta:
a. $\mathrm{A} 01=\mathrm{Jl}$. Sultan Syahrir Surakarta
b. $\mathrm{A} 02=\mathrm{Jl}$. Mashela Widuran Surakarta
c. $\mathrm{A} 03=$ Pasar Kliwon Surakarta
d. $\mathrm{A} 04=\mathrm{J} 1$. Adi Soemarmo Surakarta
e. $\mathrm{A} 05=\mathrm{J} 1$. RE Martadinata Sewu Jebres

Hasil penilaian dapat dilihat pada Tabel 9.
Tabel 9. Penilaian Hasil Survei Kelayakan Lokasi

\begin{tabular}{llcccc}
\hline Alternatif & LS & PP & K & HS & LA \\
\hline A01 & 8,6 & 8,5 & 8 & 5 & 9 \\
A02 & 8,6 & 8 & 8 & 8 & 9 \\
A03 & 8,6 & 8 & 7 & 8 & 8 \\
A04 & 8,3 & 8,5 & 8 & 3 & 9 \\
A05 & 8,6 & 8,5 & 6 & 8 & 9 \\
\hline
\end{tabular}

Dari data penilaian diatas maka selanjutnya akan dibuat perbandingan antar alternatif. Tujuannya adalah untuk mengetahui bobot nilai alternatif setiap kriteria. Hitunglah perbandingan dari semua berpasangan alternatif kriteria LS, PP, K, HS dan LA.contoh salah satu alternative yang ditambilkan adalah alternative pasangan untuk iS yang dapat dilihat pada tabel 10 Matrik perbandingan berpasangan Alternatif kriteria PP.

Tabel 10. Matriks Perbandingan Berpasangan aternatif kriteria LS

\begin{tabular}{lcccccc}
\hline Alternatif & A01 & A02 & A03 & A04 & A05 & $\begin{array}{c}\text { Bobot } \\
\text { Alternatif }\end{array}$ \\
\hline A01 & 1 & 1 & 2 & 1 & 1 & 0.22 \\
A02 & 1 & 1 & 2 & 1 & 1 & 0.22 \\
A03 & $1 / 2$ & $1 / 2$ & 1 & $1 / 2$ & $1 / 2$ & 0.11 \\
A04 & 1 & 1 & 2 & 1 & 1 & 0.22 \\
A05 & 1 & 1 & 2 & 1 & 1 & 0.11 \\
\hline
\end{tabular}

Dengan cara perhitungan yang sama seperti penghitungan bobot kriteria di atas, diperoleh bobot masing-masing alternatif berdasarkan kriteria. Masingmasing nilai entri bobot alternatif disintesa dengan bobot kriteria yang telah diperoleh dari analisa pada tabel diatas. Hal ini untuk mendapatkan bobot alternatif terbesar dengan pertimbangan kriteria tertentu. Setelah hasil sintesa diperoleh, kemudian dijumlahkan untuk memperoleh nilai bobot akhir seperti tercantum pada Tabel 11.

Tabel 11. Hasil Penilaian Akhir SPK Metode AHP Pemilihan Lokasi Kafe

\begin{tabular}{|c|c|c|c|c|c|c|c|}
\hline & \multicolumn{6}{|c|}{ Bobot Prioritas } & \multirow[b]{2}{*}{$\begin{array}{c}\text { Rankin } \\
\mathrm{g}\end{array}$} \\
\hline & $\mathrm{LS}$ & $\mathrm{PP}$ & $\mathrm{K}$ & HS & LA & $\begin{array}{c}\text { Hasi } \\
1 \\
\end{array}$ & \\
\hline A0 & 0.22 & 0.27 & 0.28 & 0.07 & 0.23 & 0.23 & 1 \\
\hline 1 & $\begin{array}{c}\mathrm{x} \\
0.31\end{array}$ & $\begin{array}{c}\mathrm{X} \\
0.33\end{array}$ & $\begin{array}{c}\mathrm{x} \\
0.16\end{array}$ & $\begin{array}{c}x \\
0.10\end{array}$ & $\begin{array}{c}\mathrm{x} \\
0.10\end{array}$ & 5 & \\
\hline $\mathrm{A} 0$ & 0.22 & 0.09 & 0.28 & 0.30 & 0.23 & 0.19 & 4 \\
\hline 2 & $\begin{array}{c}\mathrm{x} \\
0.31\end{array}$ & $\begin{array}{c}\mathrm{x} \\
0.33\end{array}$ & $\begin{array}{c}x \\
0.16\end{array}$ & $\begin{array}{c}\mathrm{x} \\
0.10\end{array}$ & $\begin{array}{c}x \\
0.10\end{array}$ & 6 & \\
\hline $\begin{array}{l}\text { A0 } \\
3\end{array}$ & $\begin{array}{c}0.11 \\
x \\
0.31\end{array}$ & $\begin{array}{c}0.27 \\
x \\
0.33\end{array}$ & $\begin{array}{c}0.28 \\
x \\
0.16\end{array}$ & $\begin{array}{c}0.04 \\
x \\
0.10\end{array}$ & $\begin{array}{c}0.23 \\
x \\
0.10\end{array}$ & $\begin{array}{c}0.19 \\
7\end{array}$ & 3 \\
\hline $\begin{array}{l}\mathrm{A} 0 \\
4\end{array}$ & $\begin{array}{c}0.22 \\
\mathrm{X} \\
0.31\end{array}$ & $\begin{array}{c}0.09 \\
x \\
0.33\end{array}$ & $\begin{array}{c}0.28 \\
x \\
0.16\end{array}$ & $\begin{array}{c}0.30 \\
x \\
0.10\end{array}$ & $\begin{array}{c}0.08 \\
x \\
0.10\end{array}$ & $\begin{array}{c}0.15 \\
3\end{array}$ & 5 \\
\hline $\begin{array}{l}\text { A0 } \\
5\end{array}$ & $\begin{array}{c}0.11 \\
\mathrm{X} \\
0.31\end{array}$ & $\begin{array}{c}0.27 \\
x \\
0.33\end{array}$ & $\begin{array}{c}0.28 \\
x \\
0.16\end{array}$ & $\begin{array}{c}0.30 \\
x \\
0.10\end{array}$ & $\begin{array}{c}0.23 \\
x \\
0.10\end{array}$ & 0.22 & 2 \\
\hline
\end{tabular}


Dari hasil tabel 11 tersebut diatas alternatif lokasi 1 1. Halaman Data Kriteria

dengan nilai tertinggi yaitu 0,235 merupakan lokasi yang paling direkomendasikan dalam pemilihan lokasi pembangunan kafe. Sedangkan lokasi yang paling tidak direkomendasikan adalah alternatif lokasi 4 dengan nilai terendah yaitu 0,153 .

\subsection{Perancangan Sistem}

Untuk perancangan system di modelkan mengunakan use case dan class diagram yang merupakan diagram UML (Unified modeling Language) yang berfungsi memodelkan user yang berinteraksi dengan sistem. Diagram Use Case dan Class diagram untuk Sistem pendukung keputusan menentukan Lokasi Cafe ditunjukan pada gambar 3 dan gambar 4.

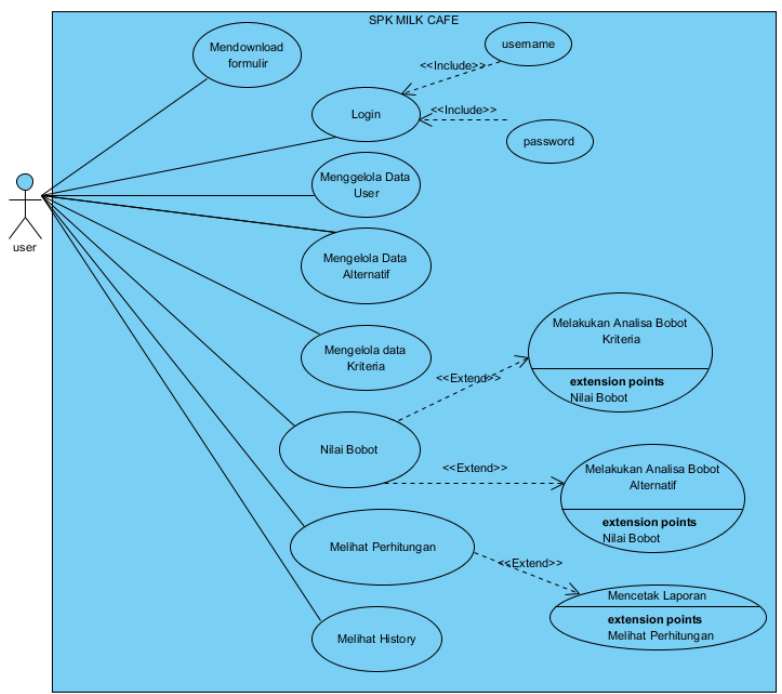

Gambar 3. Use Case Diagram SPK AHP The Milk

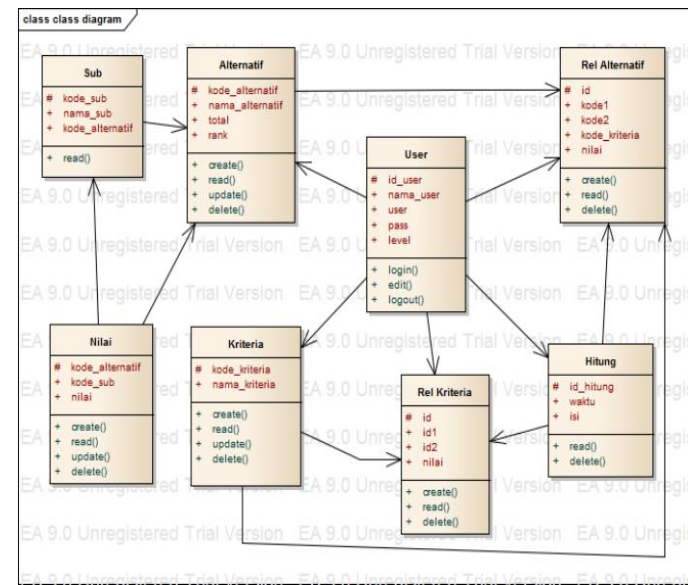

Gambar 4. Class Diagram SPK AHP The Milk
Untuk melakukan perhitungan sistem pendukung keputusan, sebelumnya pengguna melakukan input data kriteria yang dapat dilihat pada gambar 5 .

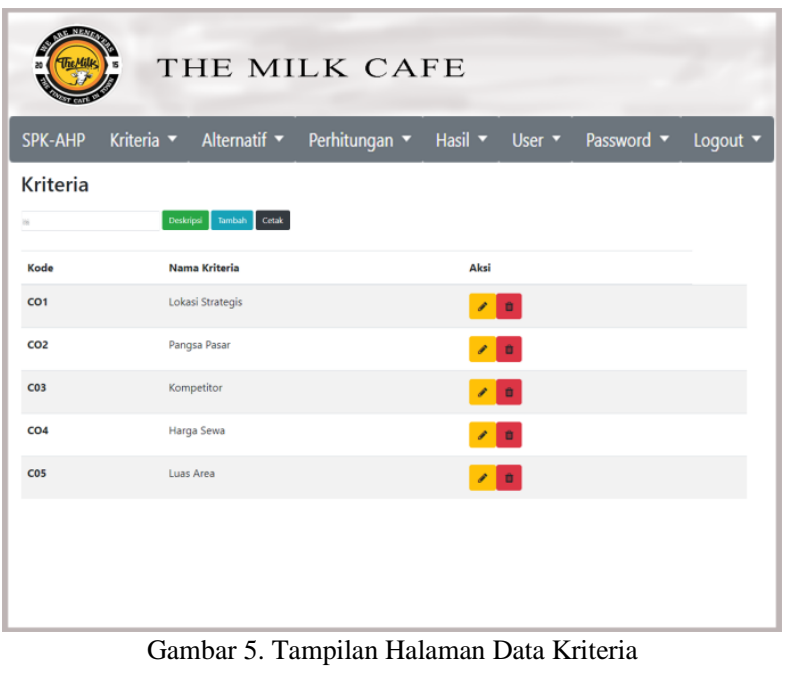

\section{Halaman Data Alternatif}

Untuk melakukan perhitungan sistem pendukung keputusan, setelah pengguna melakukan input data kriteria, selanjutnya adalah input data alternatif. Data alternatif lokasi yang dimasukan pada tabel berikut ini merupakan data alternatif lokasi hasil survei di kota Surakarta. Halaman data alternatif dapat dilihat pada gambar 6.

THE MILK CAFE
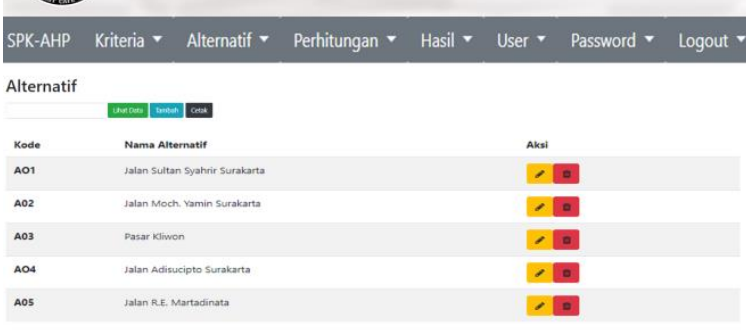

Gambar 6. Tampilan Halaman Data Alternatif

\section{Halaman Bobot Kriteria}

Langkah selanjutnya untuk melakukan perhitungan adalah menginput nilai perbandingan matriks berpasangan antar kriteria. Tujuannya adalah untuk mendapatkan bobot nilai kriteria. Untuk input nilai perbandingan dapat dilihat pada gambar 7 .

\subsection{Hasil Perancangan Aplikasi}

Berikut adalah gambar-gambar dari tampilan aplikasi SPK penentuan lokasi Café. 


\section{THE MILK CAFE}

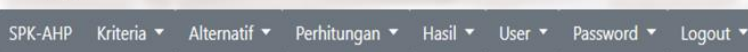

\section{Nilai Bobot Kriteria}

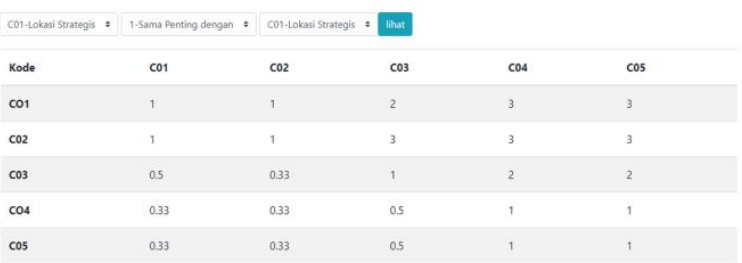

Gambar 7. Tampilan Halaman Bobot Kriteria

\section{Halaman Bobot Alternatif}

Langkah selanjutnya untuk melakukan perhitungan adalah menginput nilai perbandingan matriks berpasangan antar alternatif setiap kriteria. Halaman bobot alternatif dapat dilihat pada gambar 8 .

\section{THE MILK CAFE}

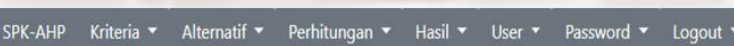

Nilai Bobot Alternatif

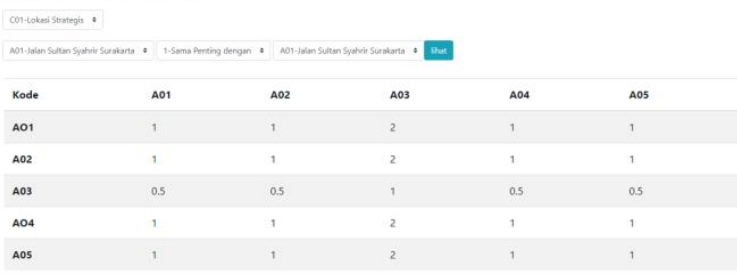

Gambar 8. Tampilan Halaman Bobot Alternatif

\section{Halaman Perhitungan}

Halaman ini adalah hasil dari perhitungan akhir dari SPK Milk Café. Halaman perhitungan dapat dilihat pada gambar 9 .

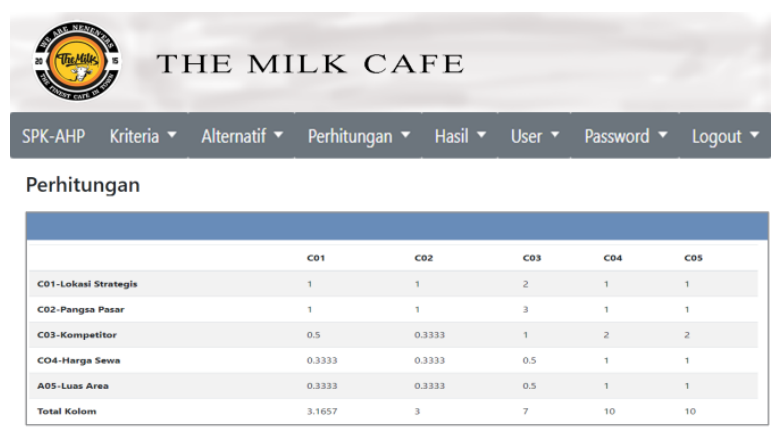

Gambar 9. Tampilan Halaman Perhitungan

\section{Kesimpulan}

Berdasarkan penelitian dan pembahasan yang dilakukan, maka dapat disimpulkan beberapa hal sebagai berikut.

1. Dari hasil perhitungan sistem pendukung keputusan Metode Analytical Hierarchy Process ini dapat disimpulkan bahwa alternatif lokasi Jl. Sultan Syahrir Surakarta dinyatakan sebagai lokasi yang paling cocok untuk dipilih sebagai lokasi cabang baru The Milk Café dengan bobot nilai paling tinggi yaitu 0,235. Sementara alternatif lokasi yang paling tidak direkomendasikan adalah alternatif lokasi Jl. Adi Soemarmo dengan total bobot paling sedikit adalah 0,153 .

2. Aplikasi Sistem pendukung keputusan ini merupakan merupakan tool yang memberikan saran lokasi yang dapat membantu pemilik Café untuk menentukan lokasi yang paling tepat.

\section{Daftar Rujukan}

[1] Acharya, V., Sharma, S. K., \& Kumar Gupta, S. (2018). Analyzing the factors in industrial automation using analytic hierarchy process. Computers and Electrical Engineering, 71, 877-886.

[2] Fitriyani. (2016). Sistem Pendukung Keputusan Pemilihan Mahasiswa Berprestasi di STMIK Atma Luhur Pangkalpinang dengan Menggunakan Metode Analytical Hierarchy Process (AHP). Jurnal Nasional Teknologi Dan Sistem Informasi, 2(2), 109-118.

[3] Frieyadie, F., \& Ramadhan, S. M. (2018). Penerapan Metode AHP Untuk Membantu Siswa Memilih Jurusan Yang Tepat Di SMK. Jurnal RESTI (Rekayasa Sistem Dan Teknologi Informasi), 2(3), 662-667.

[4] Rosiska, E. (2018). Penerapan Metode Analitycal Hierarchy Process (AHP) dalam Menentukan Mitra Usaha Berprestasi. Jurnal RESTI (Rekayasa Sistem Dan Teknologi Informasi), 2(2), 479-485.

[5] Kyaw, E. E. S., \& Lai Lai Win Kyi. (2014). Decision Making System for Job Seeking by Using AHP. Ijccer, 2(2), 57-61.

[6] Sri, I., Khotimah, K., \& Sari, K. P. (2000). Pemilihan Cafe Terbaik Menggunakan Metode Analytical Hierarchy Process ( Ahp). Jurnal Management Sistem Informasi Dan Teknologi, 11(3), 287-301.

[7] Kusrini. 2007. Konsep dan Aplikasi Sistem Pendukung Keputusan. Penerbit Andi, Yogyakarta.

[8] Darmanto, E., Latifah, N., \& Susanti, N. (2014). Penerapan Metode Ahp (Analythic Hierarchy Process) Untuk Menentukan Kualitas Gula Tumbu. Simetris : Jurnal Teknik Mesin, Elektro Dan Ilmu Komputer, 5(1), 75.

[9] Agnia Eva Munthafa, H. M. (2017). Penerapan Metode Analytical Hierarchy Process dalam Sistem Pendukung Keputusan Penentuan Mahasiswa Berprestasi. Jurnal Siliwangi, 3(2), 192-201.

[10]Priatna, W., \& Nugroho, A. (2019). Sistem Pendukung Keputusan Untuk Penentuan Dosen Favorit Menggunakan Simple Additive Weighting ( SAW ). (4), 181-190. 